\title{
Why, how, and how far should microbiological contamination in a coastal zone be mitigated? An application of the systems approach to the Thau lagoon (France)
}

\author{
Rémi Mongruel $^{a, *}$, Alice Vanhoutte-Brunier ${ }^{\mathrm{a}}$, Annie Fiandrino ${ }^{\mathrm{b}}$, François Valette $^{\mathrm{c}}$, \\ Johanna Ballé-Béganton ${ }^{d}$, José A. Pérez Agúndez ${ }^{a}$, Nicola Gallai ${ }^{c}$, Valérie Derolez ${ }^{b}$, \\ Sébastien Roussel ${ }^{\mathrm{c}, \mathrm{e}}$, Michel Lample ${ }^{\mathrm{d}}$, Thierry Laugier ${ }^{\mathrm{b}}$
}

\author{
a Ifremer, Marine Economics Unit, UMR Amure, CS 10070, 29280 Plouzané, France \\ b Ifremer, Environment and Resource Laboratory of Languedoc-Roussillon, Boulevard Jean Monnet, BP 171, \\ 34203 Sète Cedex, France \\ c Université Montpellier 1, UMR 5474 LAMETA, Avenue Raymond Dugrand, CS 79606, 34960 Montpellier Cédex, \\ France \\ d University of Brest, UMR Amure, CS 10070, 29280 Plouzané, France \\ e Université Montpellier 3 Paul Valéry, 34199 Montpellier, France
}

*: Corresponding author : Rémi Mongruel, email address : Remi.Mongruel@ifremer.fr

\begin{abstract}
:
This paper describes the building of an integrated simulation tool based on a systems approach, and its contribution to local political discussion of the mitigation of microbiological contamination of the water in a coastal area. Local management schemes view water quality as a high-priority environmental objective. In practice, how far this objective is achieved depends on trade-offs between the costs of improved water treatment facilities and the acceptable impacts of water contamination. An in-the-field experiment in collaboration with local managers was carried out in the Thau lagoon on the French Mediterranean coast during the SPICOSA (Science and Policy Integration for Coastal System Assessment) project, from 2007 through 2011. It consisted of building a modeling platform and an integrated assessment framework for simulating exploratory scenarios. The modeling platform combines a dynamic contamination model, which represents the sources of microbiological contamination, wastewater treatment facilities, and physical mechanisms of lagoon contamination, with a prospective economic model, which estimates the patterns of development of economic activities in the area through a holistic approach. Exploratory scenarios are used to assess the risk of water contamination and the efficiency of management measures, under various assumptions about the evolution of the system. The contamination simulations suggest that the work currently planned by local authorities will be inadequate for preventing increased water pollution, and that additional but fairly inexpensive management measures for maintaining the current level of water quality should be considered. The integrated assessment framework estimates the ecological and socio-economic impacts of the various pollution mitigation policies in the broader context of possible local development patterns. The results illustrate how the systems approach may aid in the design of an applicable water policy based on operational objectives and feasible technical options.
\end{abstract}

\section{Highlights}

A coastal water policy is assessed with a model based on the systems approach. $\rightarrow$ The model simulates pollution drivers, local development patterns and governance. Risks of microbiological contamination depend more on climate than on population. Restoring high water quality in the Thau lagoon definitely appears unrealistic. Management measures should rather focus on preventing further degradation.

Keywords: Systems modeling ; Integrated assessment ; Microbiological contamination ; Technical options ; Strategic planning 


\section{Introduction}

Microbiological contamination of marine water bodies is a normal environmental concern in coastal zones that face rapid population growth. The absence or ineffectiveness of sanitation systems may create serious environmental and human health problems and have adverse effects on economic activities like aquaculture and the tourist industry. Conversely, highly efficient water treatment systems may generate excessive public and private costs. As with any water quality preservation program, mitigating the microbiological contamination of marine waters requires integrated assessments to enable decision-makers to explore the consequences of various management options (Fernandes et al. 2008). Integrated assessment in support of strategic environmental planning requires selecting the variables and relationships to be analyzed, according to the particular focus of real-world policy actions (Born and Sonzogni 1995). The systems approach, and especially the dynamic modeling of systems, has proven able to facilitate integrating ecological, social, and economic concerns into the process of regional or local multi-objective water management planning (Biswas 1976, Guo et al. 2001, Stave 2003).

This paper presents an integrated assessment framework based on the systems approach, intended to support the design of a local policy action plan for mitigating the microbiological contamination of a coastal lagoon. The case study was carried out in the Thau lagoon (Étang de Thau), located on the Mediterranean coast of France, near Montpellier, the regional capital (Figure 1), in the context of the European project SPICOSA (Science and Policy Integration for Coastal System Assessment). The lagoon covers 7,500 ha and its depth is $4.5 \mathrm{~m}$ on average. Local authorities consist of 22 municipalities. Over the past thirty years, the population increased by $40 \%$ to reach approximately 130,000 inhabitants. Main activities are fisheries and shellfish farming, tourism, leisure, sailing, and water cures. Shellfish farming occupies $20 \%$ of the lagoon and produces yearly 15,000 tons of oysters and mussels. Urban and land-use pressures are high and still increase due to the proximity of the Montpellier urban area (Roussel et al. 2007). The Thau lagoon is subject to recurrent microbiological water pollution due to demographic growth and tourism, which overwhelm the wastewater treatment system. This contamination affects traditional uses of the lagoon, mainly shellfish farming and recreational activities. Temporary bans on beach activities or shellfish sales can harm the reputation of the lagoon and adversely impact the local economy, in particular the tourist industry. Improvement of water quality in the lagoon is thus one of the core issues in political discussions regarding desirable development patterns in this coastal area (Rey-Valette et al. 2007, Roussel et al. 2007).

A regional management plan (SCOT, or Schéma de Cohérence Territorial) has fixed the local policy framework for the next 20 years (2010-2030), with a list of overall objectives for the future of the Thau lagoon: (1) economic development, increasingly dependent on tourism and balneology, (2) environment preservation, through the improvement of water quality and protection of ecosystems, and (3) preservation of socio-cultural traditions, including shellfish farming, fishing in the lagoon, and recreational activities. The local water management plan (SAGE, or Schéma d'Aménagement et de Gestion des Eaux), which has seniority over the SCOT plan in the French administrative system, has also identified the reduction of microbiological contamination as a core issue. These management plans have defined the issue of water quality in terms of specific objectives: elimination of bans on shellfish sales, elimination of the closure of bathing areas, and improvement of the reputation of the lagoon. Current political discussions address the ways these objectives can be translated into operational planning decisions, taking into account the limited public budget and also the social acceptability of the trade-offs associated with the possibly incomplete fulfillment of each objective. 
The European project SPICOSA has developed a System Approach Framework to promote new methodologies for building integrated assessment platforms, through which the ecological, social, and economic aspects of coastal systems management can be brought together via interdisciplinary collaboration and science and policy integration (Hopkins et al. 2011). The SPICOSA project has been applied to studying the Thau lagoon in collaboration with a local public body, the SMBT (Syndicat Mixte du Bassin de Thau), which is in charge of both the coordination of the SCOT plan and the implementation of the SAGE plan. This experiment was intended to explore different combinations of management measures that might improve the water quality in the Thau lagoon, within a multi-objective political framework.

\section{Methods}

\subsection{The System Approach Framework of the SPICOSA project}

Systems science was introduced during the 1950s to facilitate cooperation among scientific disciplines (Boulding 1956). System dynamic modeling was developed later, with the initial goal of improving business and industrial organization (Forrester 1961, Forrester 1968). More recently, system dynamic modeling has become one of the most suitable approaches for dealing with environmental sustainability problems, as it makes social-ecological interactions central to a systems approach, thus facilitating interdisciplinary collaboration (Costanza and Ruth 1998, Boulanger and Bréchet 2005, Etienne et al. 2011). System dynamic models present known limits and weaknesses. First, these models are not well adapted to dealing with multiple levels or scales, except when several models are combined. Second, they cannot easily take uncertainty into account, as they are based on fixed relations between variables while consuming a high number of coefficients. For these reasons, they are highly sensitive to the assumptions formulated during the parameterization step (Boulanger and Bréchet 2003). Nevertheless, a system dynamic model is useful whenever sufficient data are available to feed it, as it allows for communication between stakeholders and scientists, making it a preferable instrument for the integrated assessment of environmental problems and the simulation of exploratory scenarios (as distinct from predictive or normative scenarios).

The systems approach and system dynamic modeling are now often recommended to expert advisers in integrated coastal zone management (ICZM) implementation (van der Weide 1993, Varghese et al. 2008). While relying on the general principles of systems thinking and system dynamic modeling (Forrester 1994), the systems approach of the SPICOSA project is intended to support integrated assessment of sustainability issues in the coastal zone, by addressing their ecological, social, and economic aspects. Simulation tools based on dynamic system modeling are used to explore alternative policy options, following a problemoriented and scenario-based approach. Platforms for integrated assessment were developed using the ExtendSim $®$ software, with special attention to creating user-friendly interfaces. The System Approach Framework (SAF) developed by the SPICOSA research community can be described as the iterative implementation of four steps (Hopkins et al. 2011):

- 1. Issue resolution: working with a group of stakeholders to identify the core sustainability problem and select one high-priority management issue for the local policy agenda.

- 2. Designing the system: defining the natural, social, and economic aspects of the coastal system by making explicit the main interactions and resulting feedback between ecological processes, human activities, and governance bodies. 
- 3. Building models: mathematical formulation of the ecological and social processes likely to explain the dynamics of the system, leading to the creation of a computerized model.

- 4. Analysis of results (and return to step 1): running simulations and interpreting the model outputs, using those scenarios, indicators, and framework for assessment already built and selected in conjunction with the stakeholder group.

\subsection{Issue resolution and system design}

Since numerous consultation forums are already concerned with the management of environmental and water quality in the Thau lagoon region, the research team chose not to assemble a group of participants specifically for the SPICOSA experiment. However, we met regularly with a small focus group of local managers, which included one representative of the SMBT and two technical experts from the local authorities. Working with the focus group, the primary policy issue was defined as "why, how, and how far to mitigate microbiological contamination of the Thau lagoon."

The system design step consists of the building of a conceptual model. In addition to its physical components (focusing on pollution processes), the model incorporates many economic and institutional features (Figure 2): human-generated polluting activities, human activities impacted, clean water standards and their enforcement (see Table 1), the microbiological contamination monitoring system, water treatment facilities, and the local economy. In the context of a multi-objective policy for water quality management, the microbiological contamination raises such issues as the efficiency of the wastewater treatment system, its improvement, and the related investment and operating costs. In practice, managers would expect to compare technical options and other management measures within the constraints of limited public budgets, and in the light of conflicting social preferences regarding the direct and indirect consequences of achievable clean water levels in the lagoon.

The legal framework that defines the lagoon's water quality classification and status includes European Directive 2006/7/EC, concerning the management of bathing water quality (EC 2006), and European Regulation 2004/854/EC, organization of controls on products of animal origin intended for human consumption (EC 2004). These regulations are based on the concentrations of Escherichia coli (E. coli) bacteria, which indicate microbiological contamination of fecal origin that can cause disease (primarily gastroenteritis) in bathers or shellfish consumers. Bathing areas can be classified as "poor," "sufficient," "good," or "excellent"; but whatever a beach's classification may be, it can be temporarily closed when the water is no longer of "sufficient" quality. ${ }^{1}$ Shellfish farming areas are classified based on data obtained after three years of monthly monitoring in several control stations (Figure 1 , REMI stations). Depending on the results of the regular monitoring and the alerts, A class areas may be closed when the E. coli concentration in shellfish exceeds $230 \mathrm{E}$. coli/ $100 \mathrm{~g}$ of flesh and intravalvular liquid; the threshold is fixed at 4,600 E. coli/ $100 \mathrm{~g}$ for B class areas. The water quality for shellfish farming in the Thau lagoon raises a policy dilemma: moving from the current $B$ classification to the A classification would improve the reputation of the lagoon, but it might also have the adverse effect of increasing the frequency of commercial bans on shellfish farming products. Thus, the farmers could argue that the A classification

\footnotetext{
${ }^{1}$ Escherichia Coli concentration must be less than $500 \mathrm{cfu} / 100 \mathrm{ml}$ based upon a $90^{\text {th }}$ percentile evaluation.
} 
should be accompanied by a zero risk of commercial banning. To fulfill all the expectations of all stakeholders would thus require very high public expenditures. ${ }^{2}$

\subsection{The integrated assessment framework}

When it appears that they are unlikely to achieve the general policy objectives that would maximize collective welfare (by responding to environmental requirements and user concerns), decision-makers can examine second-best options, such as lower environmental quality requirements, if users are willing to accept different levels of risk and residual impacts. For instance, the residual impacts of microbiological contamination on the shellfish farming sector depend also on the damage limitation measures that may be enforced. The specific policy objective of microbiological contamination mitigation is thus likely to be translated into more operational objectives by coastal zone managers. They will search for an acceptable level of residual pollution given current social preferences, available technologies, and the public budget. This is basically a matter of strategic planning, which consists in choosing a set of feasible management measures and technological options in light of the resulting social trade-offs. From that perspective, the integrated assessment framework ought to help managers to translate the overall goal of water quality improvement into more operational management decisions, consistent with broader local management planning.

An integrated assessment framework for a multi-objective water policy program is often based on a multiple-criteria analysis (Hajkowicz and Collins 2007), which compares a set of decision options against several criteria through an evaluation matrix that contains a list of indicators. In this study, we keep the multiple criteria analysis very simple by not weighting criteria or transforming indicators into commensurate units, for two conceptual reasons. First, aggregating indicators would involve the debatable assumption that acceptable trade-offs always exist, since a disadvantage on some criteria can be offset by a sufficiently large advantage on other criteria (Munda 2005). Second, weighting or ranking indicators can be seen as inconsistent with the holistic character of the systems approach, which requires that stakeholders be able to reassess their own judgments about the various possible evolutions of the system and the resulting social preferences (Renn 2006). Thus, our integrated assessment framework relies simply on the principles-criteria-indicators method (Varma et al. 2000), in which a principle provides a general objective related to the decision to be assessed, a criterion provides the expected direction of change for achieving this objective, and an indicator provides concrete information for evaluation. Previous analyses of public policies conducted with local management bodies (Rey-Valette et al. 2007) were used in order to make explicit the objectives of water policy in the Thau lagoon and to recast them as a series of principles, criteria, and indicators (Table 2).

\subsection{Modeling approach for integrated assessment of the Thau lagoon}

The integrated assessment framework includes ecological and socio-economic indicators. Since the indicators are heterogeneous in units and scale, the modeling approach combined a dynamic contamination model with a regional economic model (Figure 3).

The contamination model was developed using ExtendSim ${ }^{\circledR}$ modeling software (see user interface in Figure 4). The level of complexity of each ecological and physical component corresponds to the scale of management or to the minimum level of detail needed to describe water use accurately. At the top, a module representing the local economy includes

\footnotetext{
${ }^{2}$ It should be mentioned that after the Thau lagoon was reclassified as B in 2004, shellfish farms were forced to build purification centers. At that time, public budgets were already subsidizing those investments.
} 
several medium-term time-series from the macro-economic model, which gives the evolution of seasonal and permanent populations and urban areas per town, according to the scenario tested. The population is then allocated to the various habitats. The management block passes information to the water treatment block about possible changes of structure, implementation, and efficiency in water treatment facilities, depending on strategic exploratory scenarios. The regulation module simulates two separate monitoring networks for bathing area water and shellfish farming water: the model can generate warnings and bans on both activities and also predict the water quality classification of the lagoon using actual or hypothetical standards and monitoring devices.

The regional economic model is a prospective macro-economic production model based on physical units (MEPP), which is linked to the contamination model. This linkage allows, first, for the exploration of hypotheses about development patterns in the area and resulting changes in contamination levels on the watersheds and, second, for the assessment of the indirect effects of the direct impact of contamination on traditional uses of the lagoon when this impact affects the entire local economy. Although both models will contribute to interannual integrated assessments, they function on different time-scales: the macro-economic model is on an annual scale, the contamination model on a daily scale. In practice, the macro-economic model simulates scenarios for the development of the local economy; resulting changes in population and land use are passed on to the contamination model. The latter simulates daily contamination levels under different management options, which have a direct impact on human activities. At the end of every 5 -year simulation run, the observed variations in activity are transferred back to the macro-economic model, which then estimates the new equilibrium of the local economy.

\section{Specifications for the models}

\subsection{A dynamic model of contamination management}

\subsubsection{The watershed block}

The watershed pollution block takes into account the major sources of bacteria due to human activities or wildlife on 20 sub-catchments. The location of these sources on the watershed, their modeling, and the description of the associated treatment are mainly based on the results of the OMEGA-Thau project, which include a hydrological watershed model (Ifremer 2010, Raymond et al. 2010). Table 3 offers a brief description of the processes and parameters used. The sources of bacteria may or may not be connected to a collective sewage treatment facility. Some sources are of animal origin - the birds on the watershed and the dog population whose feces are sucked into the sewage network by urban runoff. After high rainfall events the pumping stations located on the sewage network and storm outfalls in the town of Sète can dump excess effluent. The population increases during the tourist season (June to September). Local bacteria sources not connected to waste water treatment plants (WWTP) located more than $500 \mathrm{~m}$ from the coastline are not taken into account. Other sources active in the lagoon itself (harbors/boating and seabirds) are not considered. The transfer of bacteria to the corresponding sub-catchment outlets depends on the distance of the source to the lagoon (DistLagoon) and takes into account bacteria depuration in the river ( $T_{90}$ is 10 hours in summer, 20 hours in winter). The transfer time of bacteria from a point source to the lagoon is always assumed to be shorter than the daily calculation time-scale. 


\subsubsection{The lagoon block}

Lagoon contamination is a complex process: during a rainfall event, variations in forcings (meteorological conditions and river discharges) and the low inertia of the Thau lagoon system mean that freshwater inputs and $E$. coli plumes are highly variable in both time and space. To estimate the wind-caused movement of water into the lagoon, the subsequent transport, dispersion, and mortality of $E$. coli in seawater, and the degree of shellfish contamination caused by $E$. coli inputs in the sub-catchments, a more precise and geographically diverse simulation tool is needed: the hydrodynamic Model for Application at Regional Scale (MARS-3D) (Lazure and Dumas, 2008), combined with several models of $E$. coli mortality in seawater (Fiandrino et al. 2003, Fiandrino et al. 2009, Ifremer, 2010).

However, this MARS model is too complex to be transposed into ExtendSim ${ }^{\circledR}$ software. Thus, the SPICOSA model calculates E. coli levels in seawater via "transfer functions" determined using MARS-3D simulation results. A database of 900 simulation results has been built for the twenty sub-basin outlets to track spatio-temporal change in $E$. coli levels under the specific meteorological and hydrological conditions that would produce the greatest risk of shellfish contamination. These conditions were those associated with the most critical water and E. coli loads (a 2-year rainfall return period ${ }^{3}$ ), and those favoring both $E$. coli survival in seawater $\left(T_{90}=48\right.$ hours) and the rapid transfer of $E$. coli from the plumes at river mouths to the nearest shellfish farming area. Based on the calibration/validation step of the model, we felt that five wind conditions (Table 4) would provide a sufficiently representative panel for maximal spread of the $E$. coli plume.

To determine the transfer function we point out that, in any cell $\left(C_{k}\right)$ of the MARS-3D model grid of the Thau lagoon, the temporal distribution of $E$. coli levels caused by an outlet $\left(O_{k}\right)$ can be approximated with four parameters (Figure 5): the maximal E. coli level in seawater $\left(C_{\max }\right)$ at $C_{k}$ location, the day this maximal contamination occurred $\left(T_{\max }\right)$, the days of the beginning $\left(T_{\text {begin }}\right)$ and of the end ( $\left.T_{\text {end }}\right)$ of the contamination. These four parameters depend on daily $E$. coli flux $(F)$ and distance $(D)$ between outlet $O_{k}$ and the $C_{k}$ station.

\subsubsection{The regulation block}

The regulation block simulates the monitoring managed by public authorities in the shellfish areas and some of the beaches around the lagoon. Current regulations set water quality standards and open/closed status. In shellfish areas, regular monitoring is conducted by IFREMER (French Research Institute for Exploration of the Sea) on the first Monday of each month in the REMI network, at 9 monitoring stations (Figure 1). Additional alert monitoring is done when rainfall over the two previous days exceeds $40 \mathrm{~mm}$ or information concerning wastewater system failures is received. When the $E$. coli concentration in shellfish exceeds the permissible alert threshold, a warning procedure is triggered and monitoring done every 2 days until 2 successive analyses confirm that the $E$. coli level is below the regulatory threshold. During this warning period, the authorities can decide to ban shellfish sales. One contaminated station is enough to close the whole lagoon. After 3 years, the lagoon's water quality status is assessed using the data from the regular monitoring. The regulation module is able to simulate changes in the regulations governing the water quality status of the shellfish farming area. Monitoring of bathing areas is done every 15 days during the bathing period (15 June to 15 September), on 7 beaches. The quality of each beach is assessed every year and determined independently of the others.

\footnotetext{
${ }^{3}$ More intense rainfall events (a 5-year return period was tested) do not increase microbiological contamination levels in shellfish, due to a dilution effect in the river input.
} 


\subsection{The macro-economic model}

The Macro-Economic and Physical Prospective model (MEPP) adopts the principles enunciated by Von Neumann (1945) and Sraffa (1960) in their "joint production models" for representing economic activities at the local level. These models are based on a detailed description of the resources exploited, the facilities installed, and the flows of goods and services traded within the region or between it and the rest of the world. The MEPP model essentially obeys the rule that for each of the goods and services a local balance must exist between production and consumption, including trade (imports and exports) and potential surplus:

if $\quad i$ indexes the goods and services (rows of the matrix), $1 \leq i \leq M$

$j$ indexes the activity (columns), including imports and exports, $1 \leq j \leq P$

$X_{j}$ is the level of the $j$ activity

$a_{i, j}$ is the technical coefficient that gives the production (if positive) or the consumption (if negative) of the good $i$ by the activity $j$,

$s_{i}$ is the surplus of the good (or service) indexed by $i$

then the equilibrium rule of the model, which stands for each good or service $i$, is written:

$$
\sum_{j=1}^{N} a_{i, j} \cdot X_{j}-s_{i}=0
$$

These principles can result in a huge variety of technical and socio-economic structures, because of the a priori sub-determination of the mathematical problem to be solved. The set of results can be reduced by introducing direct constraints (lower or upper bounds) on activities or an objective function for specifying a preference for a given activity. The calculation, using the classic simplex algorithm, will then maximize the $X_{j}$ values under these constraints and objectives. Three types of intervention can thus affect the MEPP model:

-constraining the values of some variables (levels of activity or surplus): if the variables are not free (the default), they can be bounded or fixed;

-choosing an optimization criterion for the calculation of the "best" solution. This may express political preferences, such as increased prosperity (by maximizing the monetary surplus from trade), quality of social life (by minimizing the surplus of work, equivalent to unemployment), or quality of the environment (by minimizing activities and/or surplus generating pollution);

-changing the technical coefficients that describe the amounts of each of the goods and services produced or consumed by the activities.

All these options for framing and controlling the model can be used to simulate a great variety of exploratory scenarios, corresponding to different assumptions about the scope for possible change in the local economic system.

In this study, the simulations made with the MEPP model were intended to assess the indirect macro-economic consequences of direct changes in some activities caused by lagoon pollution. For that purpose, the estimated direct impacts of microbiological contamination are translated into a variable activity index for shellfish farming and the tourist industry (index value $=100$ for the reference situation). This is then used as an input for a new simulation of the macro-economic model for the next 5-year period. Figure 6 presents the hypothetical response curves of these activities to changes in the lagoon's water quality. 
These two curves are based on hypotheses consistent with the results obtained by two empirical studies - an economic impact assessment of the microbiological contamination of the Thau lagoon over the period 2000-2005 (Mathé et al. 2005) and a survey of the vulnerability of shellfish farms to environmental hazards, conducted during summer 2010 on a sample of 100 oyster farms (Pérez Agúndez et al. 2010). Table 5 splits the continuous response curve into discrete water quality levels, characterized by the lagoon's water quality classification, the frequency of bans, and the corresponding activity index.

Under current conditions - B classification with only occasional bans (water quality 3) shellfish farmers face low economic losses; the complete elimination of bans would only result in a $5 \%$ increase in activity, while the highest quality level (the A classification of the lagoon) would actually decrease production, because greater efficiency of the water treatment system would also mean a reduction of the nutrient flows that feed the oysters. On the other hand, degradation of water quality from the reference state could have severe impacts. Producers might lose opportunities to sell their products when prices are high, and even lose some of their sales contracts and outlets, leading to a possible $10 \%$ decrease in their activity. Subsequently, accumulated economic losses could force producers to change their practices and invest in new technologies for purification and storage of the oysters. Since some of them would not be able to adapt in this way, a first "exit threshold" would be crossed by entire sub-groups of the industry; when combined with a "bad reputation" effect, this structural eviction mechanism could cut activity in half. Finally, the degradation of water quality into the $\mathrm{C}$ classification would mean the end of shellfish farming in the lagoon (the second exit threshold, linked to the water quality classification).

The tourist industry response curve is identical to that of the shellfish industry in the center, but it is supposed to be completely convex and its ends have thus been smoothed, for two reasons. First, there is no indication that the highest level of water quality would result in a decrease of the activity index. Second, there is no indication that eviction thresholds exist for particular categories of the tourist population, as the response of this activity to increasing pollution depends not only on adaptability (change of vacation destination) but also on willingness to accept risk, which may be highly variable according to individual preference. However, a situation in which all the beaches were closed at all times would certainly reduce the tourist industry activity index to near zero.

\section{Results}

This section describes the calibration and validation of the contamination model and the simulated exploratory scenarios. A first set of exploratory scenarios was tested in order to assess the risk of microbiological contamination under various forcing conditions. A second set, the strategic exploratory scenarios, was tested in order to check the effectiveness of various management options. Exploratory scenarios were simulated for the period 20132017, and can be compared to the 2003-2007 reference period. The results are expressed in terms of contamination levels, bans, and water quality classification. Finally, socio-economic indicators are estimated using the MEPP model to provide an integrated assessment of the most meaningful exploratory scenarios.

\subsection{Calibration and validation of the contamination model}

\subsubsection{The watershed contamination module}

The daily bacterial fluxes simulated by the SPICOSA-Thau contamination model can be compared to simulations of the OMEGA-Thau watershed model, where results are available 
for a rainfall event of $75 \mathrm{~mm}$ per day (corresponding to a 2-year rainfall return event). Figure 7 shows the contribution of each source of bacteria to lagoon contamination for such a rainfall event as computed by the SPICOSA-Thau model. Figure 8 provides a comparison of both models, in which the rainfall event occurs in summer (the period of the year with the highest population density) of 2008.

The major contamination sources of the lagoon after a rainfall event - pumping stations, storm outfalls, and urban runoff - have rainfall-dependent $E$. coli production that is 10 to 100 times greater than the other sources (those with autonomous sewage treatment facilities or connection to WWTP). Some differences occur in the sources included in the two models (birds are only simulated in the SPICOSA model, rural runoff is only simulated in OMEGAThau), because the SPICOSA model was developed on the basis of the OMEGA-Thau step 1 report, published before the OMEGA-Thau watershed contamination model (step 4). But the daily $E$. coli fluxes produced by these two sources are of comparable importance (12.7 and 12.6 respectively). In OMEGA-Thau, the river-stock is assessed at the watershed level, while in SPICOSA-Thau it is only applied to effluents of WWTP.

\subsubsection{Lagoon contamination and water quality status}

A complete data set covering 7 years (2003-2009) is available for validating the model. It includes $E$. coli concentrations in oysters at REMI monitoring stations, commercial ban events, and wind conditions from the Météo-France station at Sète. The use of transfer functions for simulating the lagoon contamination assumes that wind direction does not vary during a given rainfall event and the following days. This is unrealistic: meteorological conditions are rarely steady over many days. In order to minimize errors, an adjusted wind time series has been built, which determines the wind conditions for the whole contamination period. The SPICOSA-Thau model's results thus fit well with observations. Table 6 shows, for each of the 25 observed contamination events, the rainfall recorded at Sète the day before the monitoring, the type of monitoring (regular or alert), and the E. coli level above the water quality threshold reported or simulated at the 9 monitoring stations. Rainfall data in this table is called "project rainfall" and defined thus: if the total rainfall $R$ for 2 consecutive days exceeds $40 \mathrm{~mm}\left(R_{1}+R_{2}>40 \mathrm{~mm}\right)$, the data used is from a unique rainfall event $R p$, such that $R p_{1}=R_{1}+R_{2}, R p_{2}=0$.

Some observed contamination events cannot be simulated by the model and are not shown in this table. They concern (1) shellfish area closures due to viruses causing gastroenteritis, (2) alert monitoring after an observed failure in any sewage treatment facility, and (3) alert monitoring events occurring after observed rainfall not registered by the Météo-France station in Sète. Real data show that most of the closures (7 out of 10) are in response to alert monitoring $(A)$ and not to regular monitoring $(R)$. A few events $(1,19,20,23)$ generated by the model do not match alerts recorded in the REMI network data, one of them leading to a simulated closure: the Thau catchment is large enough to have simultaneous varying meteorological conditions (only rainfall in Sète was used in the model), which may explain those differences. The model does not reproduce the 4 contamination events $(8,15,21,22)$ detected by regular monitoring, which triggered closures of the shellfish area in April (2004, 2006 ) and August $(2007,2008)$ : these events were not related to rainfall and the model does not reproduce bacterial transfer to the lagoon during dry weather or hazardous intra-lagoon contaminations possibly caused by boats and seabirds (Derolez et al. 2010). Finally, as regards the water quality status of the shellfish farming area, the model closely matches the alerts that occurred during the validation period, omitting none of them, and generates the same number of bans as those recorded in the data for alert monitoring. 
For bathing areas, the Regional Health Agency (ARS) recorded 6 results of regular monitoring higher than the threshold value of $2000 \mathrm{cfu} / 100 \mathrm{ml}$, in 5 separate contamination events. The SPICOSA-Thau model does not show poor quality water at bathing sites on the simulated monitoring dates, because no rainfall occurred on the previous days. It is out of the question that the sub-catchments are responsible for these beach closures. Nevertheless, according to the model, the 7 beaches were contaminated by a rainfall event $(87 \mathrm{~mm}$ in 3 days) at the end of the 2006 bathing season. In addition, the ARS reports the annual classification of bathing water, varying from $A$ (good) to $C$ (temporarily contaminated), depending on the beach and the year. The model simulates continuous A classification. ${ }^{4}$ For these reasons, the simulation results for bathing water will be interpreted as only indicative, and the quality of the lagoon water will ultimately be determined according to the results obtained for the shellfish farming area.

\subsection{Exploratory scenarios: drivers of change and risk assessment}

Exploratory scenarios test the effects of external changes on the system in order to analyze the different kinds of risk associated with contamination. Four drivers of change are considered: population, wind conditions, monitoring system, and regulation implementation. The first two determine the risk that water will be contaminated, while the other two concern the risk that shellfish consumers or bathers will be exposed to contamination. The latter risk depends on the ability of governance mechanisms to assess the contamination of the lagoon and to implement effective health and safety measures for its users.

Estimates of population growth are based on projections established for the regional management plan (Pop_trend) or on a simulation by the MEPP model that maximizes the attractiveness of the area (Pop_max). The first assumption presupposes a moderate population increase $(+34 \%$ between 2007 and 2017), the second presupposes a large increase $(+86 \%)$. Wind conditions can be set using the data used to reproduce contamination events during the validation period (Wind_adjust) or using the results of simulations that maximized the number of contamination and ban events during the reference period, according to the current monitoring system (Wind_max). The monitoring equipment can be kept as it is (Monit_curr), limited to the 9 control points of the current REMI network chosen to display a mean level of contamination, or it can be transformed into a larger network (Monit_compl), based on the 39 control points proven to display the maximal level of contamination according to MARS-3D simulations. Finally, the regulation framework can be set according to three options. In the case of the classification of the shellfish farming area, it can implement the regulations introduced in 2004 but never applied (Reg_strict), or a less strict interpretation of the cumulative results of regular monitoring for the reclassification of the area (the default). ${ }^{5}$ In the case of bans on shellfish sales, the scenarios distinguish two ways of implementing the regulations: before 2010, preventive bans could occur only in September through December and only if no other ban had occurred during the year (Reg_2000), but since 2010 local authorities have decided to promulgate more systematic preventive bans if there is an alert (Reg_2010).

Our results suggest that wind conditions exert more influence on the contamination of the shellfish farming area than population change (Figure 9, top). Increasing the number of inhabitants by $39 \%$ at the end of the simulated period (Pop_max $=223,900$ inhabitants; Pop_trend $=162,600$ ) would only result in one additional ban (12 with the maximum population instead of 11 on the trend scenario), corresponding to an increase of only $9 \%$ in

\footnotetext{
${ }^{4}$ According to the 76/160/EEC regulation (Council Directive of December 8, 1975), applied to the Thau lagoon beaches through the 2009 bathing season.

${ }^{5}$ This tolerance level was finally made official with the modification of the 2004 regulation introduced in 2008.
} 
total duration of shellfish farming area closures. But worst-case wind conditions would generate 17 closure events and a corresponding increase of the duration of the bans by $48 \%$ for the highest population growth and $61 \%$ for the trend scenario. However, the impact of population growth seems to be predominant as regards the contamination of beaches: the number of days above the alert threshold, which was limited to 5 in the reference period, already rises to 10 and 11 with both population scenarios for 2013-2017, slightly more (12 and 13) under worst wind conditions. Whatever the increase in alerts and bans, the lagoon would still be classified B for shellfish farming and "excellent" for beaches. Nevertheless, if the classification procedure for shellfish farming areas had been implemented as was initially scheduled before the modification of the 2004 regulation, the lagoon would have been at risk of being reclassified as $\mathrm{C}$ under 3 of these scenarios (Pop_max with both wind conditions, and Pop_trend for Wind_max conditions), whatever the monitoring system (see detailed results of all simulations in the Appendix).

The contamination model can also be used to assess the influence of governance changes on alerts and bans in shellfish farming areas (Figure 9, bottom). Governance scenarios are implemented using the SCOT population hypothesis (Pop_trend). The way the regulation was implemented before 2010 (Reg_2000), which required two conditions for introducing preventive bans, would have cut the number of bans by half ( 9 instead of 17) for an equal number of alerts. This illustrates how the same level of contamination may lead to different levels of consumer protection, depending on the practices of local authorities. Changes in the monitoring equipment may also indicate how close to reality is the perception of the level of contamination of the lagoon by experts and the public authorities. Under the worst wind conditions, the REMI monitoring stations are impacted by each contamination event, so a change in the monitoring system would not increase the number of alerts and bans. However, under adjusted wind conditions, the complete monitoring system would detect 6 additional breaches of the alert threshold (32 instead of 26), leading to 4 additional bans on shellfish sales (15 instead of 11).

\subsection{Strategic exploratory scenarios: effectiveness of management options}

The strategic exploratory scenarios assess the effectiveness of the management measures aimed at reducing the microbiological contamination of the lagoon. These scenarios do not take governance changes into account (regulation is that of the 2010 modification and the monitoring system is the same), but include population and climate changes that generate different levels of water contamination, in order to account for the entire pollution risk. Four management measures targeting the mitigation of bacterial production are tested, with their successive and cumulative implementations in 2010-2012, so that their effects are operative for simulating 2013-2017.

The first management measure (Planned_WWTP) covers work on the wastewater treatment plant (WWTP) planned by local municipalities in two areas: increasing the nominal capacity of the Mèze WWTP and connecting three municipalities in the northeast area (Poussan, Gigean, and Bouzigues) to the Sète WWTP, whose outlet is in the Mediterranean. The second measure (Planned_PS) is the improvement of the efficiency of a series of pumping stations identified as the greatest polluters by the OMEGA-Thau project; the efficiency gains are simulated using the assumptions selected in this project. The third measure (Option_PS) is the optional upgrading of all the pumping stations in the sub-catchments close to Mèze (Pallas, Sesquier, Port de Mèze). The simulation is based on the assumption that these pumping stations will not experience any failures, whereas they spilled sewage effluent during each of the 19 rainfall events above $40 \mathrm{~mm}$ during the reference period. The final management measure (Option_UR) is street cleaning of urban areas every 3 days, by vacuuming. This technical option would remove bacteria previously transferred to the lagoon through urban runoff. It is assumed to be much more effective than washing the streets, 
which is equivalent to artificial rainfall and leads to an additional release of bacteria into the watersheds.

Table 7 depicts the strategic management choices and corresponding combinations of technical options implemented in the contamination model to simulate strategic exploratory scenarios, while allowing for various types of change introduced by external drivers. The baseline scenario (Strat_0) is a "business-as-usual" scenario: it estimates the situation in 2013-2017 as if none of the planned technical improvements had been implemented. The first strategic scenario (Strat_1) highlights the projected effects of the planned management measures. The two other strategic scenarios show the incrementally positive effects of technical options for pumping stations (Strat_2) and street cleaning in urban areas (Strat_3). The results of the simulations, expressed using the usual 4 indicators (number of bans on shellfish sales, duration of these bans, number of days above alert thresholds for shellfish farming and for beaches) are then translated into the synthetic indicator of water quality level, as shown in Table 5.

The simulation results are compared to the value of indicators during 2003-2007: with 7 bans on shellfish sales of a total duration of 48 days and 5 days above the water quality threshold for beaches, the water quality of the lagoon is considered to be category 3 in the reference situation. For 2013-2017, the baseline scenarios (Strat_0) indicate that the lagoon could fall into category 4 under moderate risk conditions (exploratory conditions 1 and 2 in Table 8) and into category 5 under high risk conditions, due to worst-case wind conditions (exploratory conditions 3 and 4, both considering Wind_max). However, the capacity of the planned management measures (Strat_1) to mitigate the impact of water pollution is very low. They only prevent one ban on shellfish sales under the moderate population assumption (Pop_trend), and none under the maximum population growth assumption (Pop_max); their sole significant effect regards the beaches, whose condition might be improved by one level, but only in the case of moderate population growth. Consequently, the planned management measures are unable to significantly contain contamination sources, and would not enable the lagoon to recover its initial level of quality. Optional management measures should thus be contemplated to avoid water quality degradation. Additional work on the pumping stations (Strat_2) would cut the number of shellfish sale bans by $18 \%$ to $25 \%$ depending on wind conditions and population growth. This would result in an improvement of the lagoon situation by one level of quality, insufficient for restoring the initial level in the most risky situation (exploratory conditions 3 and 4). Street cleaning (Strat_3) has no incremental effect under the maximum population growth assumption. However, under the moderate population growth assumption, this strategy would cut the risk of shellfish sale bans by more than $50 \%$ and maintain the lagoon at its initial quality level, under all wind conditions. Its effect on beaches is also positive but much less significant.

\subsection{Integrated assessment}

The integrated assessment estimates four socio-economic indicators for each of the water quality levels possibly reachable at the end of the exploratory scenarios (2017), depending on the corresponding activity index of the shellfish farming sector and the tourist industry (see Table 5): employment in traditional activities (oyster farming, mussel farming, and lagoon fisheries), number of tourist visits, total employment, and trade balance (difference between exports and imports). Results are presented in Table 9. For comparison, during the year 2007, which corresponds to water quality level 3, traditional activities employed 1991 people and the region saw a total of 25 million overnight visitor stays.

First, it appears that the response of the local economy to changes in water quality depends substantially on population growth patterns. Under moderate population growth, maintaining 
the lagoon waters at the same quality level would preserve the total amount of jobs in traditional activities. Conversely, very high population growth would adversely impact employment in the traditional sectors, even with maintained water quality. This may be due to the attractiveness of other sectors that provide opportunities for easier jobs. Thus, given high demographic pressure, the traditional sectors could see a move toward more capitalintensive production techniques. In particular, it is noticeable that high population growth would also entail reduction of employment in the agriculture sector, by comparison with the moderate population growth scenario. However, not surprisingly, the high population growth scenario is the one more likely to maximize the criteria related to the broad objectives of economic development: total number of jobs and trade balance.

Results obtained for poor water quality (levels 4 and 5) suggest that increasing pollution has much more impact on traditional activities and the tourist industry in the case of high population growth than in that of moderate population growth. Thus, a local development pattern favoring population growth, which would be intrinsically detrimental to traditional activities and tourism, would also accelerate the negative effects of water quality degradation if no effective management measures were implemented. Lastly, macro-economic indicators (total employment and trade balance) are much less sensitive to water quality. Whatever the impacts of water quality on traditional activities and the tourist industry might be, the overall economy would be able to adjust at least in terms of overall employment. The effect of water degradation on the trade balance might be slightly negative in the case of moderate population growth, or even slightly positive in the case of high population growth, suggesting many possible forms of adjustment within the local economy viewed at the regional level.

\section{Discussion}

The watershed contamination model is developed in simple terms, without any description of the hydrological network. However, the daily E. coli fluxes computed for each source type at the outlets fits well with the results of a more complex watershed hydrological model developed during the OMEGA-Thau project. This model-to-model comparison was the only feasible validation test, as the field campaigns had a time-scale that did not fit the computed daily fluxes, were focused on a few sub-catchments outlets, and were not suited to largescale validation. At this stage of development, the watershed module of the contamination model could be improved for sources of minor importance (river-stock and rural runoff).

The validation of shellfish area contamination after rainfall events is convincing, even though the hazardous pollution events due to boats and birds in the neighborhood of shellfish grounds, while potentially important (Sobsey et al. 2003, Derolez et al. 2010), cannot be reproduced. The same problem concerns bathing water quality, which may be mainly degraded by the bathers themselves. Future work may include these local contaminations. The dynamic contamination model can be run very quickly because it integrates information provided by hydrological models of different areas of the lagoon and its sub-catchments. This rapidity has turned out to be very useful in discussions with stakeholders. It has been made possible by previous work that defined transfer functions of bacteria under many wind conditions. However, that study showed the limits of transfer function calibration under steady wind conditions, which led us to build time-series using adjusted wind conditions.

The joint implementation of the contamination model and the macro-economic model produces quite realistic simulations, based on a fairly large amount of empirical knowledge regarding the drivers, processes, and consequences of microbiological contamination in the Thau lagoon. Linking the models is not simple, and involves some important "off model" decisions, introduced on a case by case basis. This is true in particular for the response curve of human activities to water contamination: any modification of the assumptions used 
to build activity indexes would of course introduce significant changes in the processed data. In other words, changes in the local economy described by the MEPP are not necessarily to be interpreted as linked to changes in water quality in the lagoon, and some of these economic changes may also be seen as resulting from assumptions of the scenarios. This level of uncertainty could be reduced by additional field data regarding the dynamics of impacted activities that were not available at the time the simulation platform was built.

Although useful, these improvements are not necessary for implementing exploratory scenarios. Indeed, exploratory scenarios are not intended to predict future states of the system nor to define one single reachable desired state; they should be used to explore possible evolutions of a complex system, including a wide range of drivers of change and the influence of the monitoring and regulation devices, so as to assess the relative effectiveness of various management options.

The results of the simulations suggest a hierarchy of drivers of change that affect water quality in the Thau lagoon. Above a given threshold, population growth generates no additional risks, while wind conditions exert much more influence on the occurrence of contamination events, whatever the population growth may be. This is certainly to be explained by the mechanisms of microbiological contamination, which is mainly due to intense but occasional rainfall events. As regards the evolution of climate conditions, pessimistic exploratory scenarios should contemplate the risk that these intense rainfall events may become more frequent, or more frequently associated with adverse wind conditions. From this point of view, the main objective of the water pollution mitigation policy should be to consider feasible options for coping with extreme rainfall.

The model highlights possible discrepancies between "real" contamination and that observed by the current monitoring system. Our results confirm that the current monitoring system, built to display a mean level of contamination, is unable to detect all the contamination that may occur within the shellfish farming area. It may be argued that the evolution of the way the regulation is implemented, toward more preventive closures, is intended to offset a possible deficit in risk assessment by a higher level of consumer protection. Public authorities have to cope with the uncertainty inherent in any monitoring system that relies on discrete and spot observations for a phenomenon that may be continuous and diffuse, especially as regards the coastal waters of a lagoon.

Connecting the northeast area to the Sète WWTP would contribute to building a "green belt" around the Thau lagoon. This strategy means a diversion of the pollution problem toward the sea, with probably few risks of microbiological contamination of beaches on the Mediterranean coast. But it appears to be unrealistic to expect significant improvement of the lagoon's water quality status and its reclassification as an "A-class area" for shellfish farming. Shellfish farmers have already adapted their equipment to the current B classification, and they are much more interested in limiting shellfish sale bans than in improving the lagoon's classification. Because our simulations suggest that the planned management options plus the optional ones would still not achieve A classification, this goal seems definitely incompatible with available public budgets. However, efforts are still necessary to reduce the occurrence of food-borne disease outbreaks due to viral contamination of shellfish during winter gastroenteritis epidemic periods.

Contrary to the expectations of local decision-makers, strategic exploratory scenarios suggest that the planned management measures will not achieve the objective of water quality preservation, whatever the population change may be. Further improvement of the pumping stations appears to be needed. This would have a fairly good cost-effectiveness ratio if implemented in a single area, preferably the one that generates the highest bacterial fluxes. The effectiveness of street cleaning measures is dependent on the population growth pattern: high population growth would reduce the incremental effect of this measure to near- 
zero. One hypothesis might be that street cleaning is ineffective in urban areas whose population growth is so high that their basic wastewater treatment facility can no longer handle regular contamination sources. In particular, high population growth will result in exceeding the carrying capacity of the WWTP of some small towns. High population growth can also be accompanied by habitat dispersion, which would make street cleaning difficult or very expensive. This is why new urban areas should not be allowed to create large impermeable surface areas, in order to mitigate as far as possible the negative effects of urban run-off.

Lastly, the importance of the population growth trajectory for choosing operational management options is confirmed by the simulation of the local economy after the implementation of these measures. As regards the general objectives of economic development, based on job creation and favorable trade balance, any pattern of population growth would be compatible with positive outcomes. On the other hand, the objective of maintaining traditional activities and the tourist industry is more likely to be achieved in the context of moderate population growth, for two reasons. First, high population growth may have direct adverse effects on the primary sectors and tourism because of its impact on natural resources and landscapes; second, it may impede the effectiveness of technical measures for preserving water quality.

\section{Conclusion}

Building an integrated simulation tool based on the systems approach contributes to the further understanding of the biophysical mechanisms and social issues raised by microbiological contamination in the coastal zone. While drawing on knowledge produced by other research and management projects in the Thau lagoon, the modeling platform developed for the SPICOSA experiment provides at least two innovative insights. First, it demonstrates that including governance mechanisms in a dynamic contamination model allows for a pollution impact assessment that clearly distinguishes real contamination, observed contamination, and risk management. Second, it shows that combining a macroeconomic model with a dynamic contamination model at a local level may be an effective way to produce an integrated assessment of the issue of microbiological contamination, considering exploratory scenarios which can take account of different development patterns within one region as well as various strategic management decisions.

The results of the simulated exploratory scenarios suggest that the risk of increased water contamination in the future may be driven not so much by population growth but rather by change in climate conditions, toward more frequent and intense rainfall events associated with adverse wind conditions. In addition to upgrading the water sewage network and wastewater treatment plants, the most effective management measures for preserving water quality may be focusing on pollution mitigation measures in targeted areas and implementing pollution prevention measures such as street cleaning or the limitation of impermeable surfaces in new urban areas. However, the effectiveness of any of these management measures will always depend on both demographic context and economic development patterns.

Exploratory scenarios, including change in contamination drivers, regulation implementation, and strategic planning, are helpful in designing complex multi-objective management policies and in translating the general objective of water quality improvement into more operational objectives. At least as regards microbiological contamination, and bearing in mind existing feasible technical options, the objective of restoring high water quality (A classification for the shellfish farming area) in the Thau lagoon definitely appears unrealistic, and management 
measures should focus rather on preventing further degradation. Accompanying measures for pollution impact remediation should also be considered.

Comparing different demographic scenarios with an integrated assessment framework highlights possible discrepancies between the different principles underlying a multi-objective local development policy. The high population growth scenario produces better results in terms of economic development for the whole region. However, it is much more likely to be accompanied by high levels of water pollution, adversely impacting traditional activities. In particular, if this kind of development pattern were preferred by decision-makers, it would probably mean a switch in water policy objectives toward increased support for remediation measures related to the impacted activities, at the expense of prevention measures related to coastal water protection. This in turn could accelerate changes in traditional activities. For instance, if forced to cope with more frequent contamination events, the shellfish farming sector might undergo structural transformation, since the technical equipment needed for production in these degraded environmental conditions might not be universally accessible.

A deeper understanding of how far such conflicting objectives can be reconciled in a time of increasing pressure on coastal waters would require further methodological research. Such a development of the integrated assessment tool could, for instance, investigate the vulnerability of shellfish farming businesses and the tourist industry to environmental hazards, or the public's perception of water quality. It could be complemented by an estimate of the marginal costs of improved water treatment facilities, to build a framework for a multicriteria cost-effectiveness analysis.

\section{Acknowledgements}

This work was funded by the European Commission under the $6^{\text {th }}$ Framework Programme, Priority 1.1.6.3 "Global Change and Ecosystems" (project N²007-036992)

\section{References}

Biswas A.K., 1976. Systems Approach to Water Management. New York, McGraw-Hill, 429 pp.

Born S.M., Sonzogni W.C., 1995. Integrated environmental management: Strengthening the conceptualization. Environmental Management, 19(2): 167-181.

Boulanger P.-M., Bréchet T., 2003. Modélisation et aide à la décision pour un développement durable: état de l'art et perspectives. Rapport final au SPP Politique Scientifique (SPP-PS), Action de support AS/F5/01, Institut pour un Développement Durable, Belgium. $161 \mathrm{pp}$.

Boulanger P.-M., Bréchet T., 2005. Models for policy-making in sustainable development: The state of the art and perspectives for research. Ecological Economics, 55(3): 337-350.

Boulding K.E., 1956. General System Theory, the Skeleton of Science. Management Science, 1956: 197-208.

Costanza R., Ruth M., 1998. Using Dynamic Modeling to Scope Environmental Problems and Build Consensus. Environmental Management, 22(2): 183-195.

Derolez V., Serais O., Caprais M.-P., Le Saux J.-C., Messiaen G., 2010. Investigating an avian source of shellfish faecal contaminations in the Thau lagoon (Mediterranean, France). Proceedings of the ICMSS $7^{\text {th }}$ International Conference, Nantes, June 14-19 2009. Available at <www.Symposcience.org> 
EC, 2004. Regulation 2004/854/EC of the European Parliament and of the Council of 29 April 2004 laying down specific rules for the organisation of official controls on products of animal origin intended for human consumption. OJEU, L26: 83-127.

EC, 2006. Directive 2006/7/EC of the European Parliament and of the Council of 15 February 2006 concerning the management of bathing water quality and repealing Directive 76/160/EEC. OJEU, L64: 37-51.

Etienne, M., Du Toit D. R., Pollard S., 2011. ARDI: a co-construction method for participatory modeling in natural resources management. Ecology and Society, 16(1): 44. URL: http://www.ecologyandsociety.org/vol16/iss1/art44/

Fernandes A. M., Kirshen P., Vogel R. M., 2008. Optimal Siting of Regional Fecal Sludge Treatment Facilities: St. Elizabeth, Jamaica. Journal of Water Resources Planning and Management, 134(1): 55-63.

Fiandrino A., Cesmat L., Dumas F., Jouan M., Laanaia N., 2009. A hydrodynamic model for Mediterranean lagoons (MARS-3D): calibration and estimation of water residence time in the Thau lagoon (France). Poster Session at the European Conference on Coastal Lagoon Research, December 14-18 2009, Montpellier, France.

Fiandrino A., Martin Y., Got P., Bonnefont J.L., Troussellier M., 2003. Bacterial contamination of Mediterranean coastal seawater as affected by riverine inputs: simulation approach applied to a shellfish breeding area (Thau lagoon, France). Water Research, 37(8): 17111722.

Forrester J.W., 1961. Industrial Dynamics. Waltham, MA, Pegasus Communications, 464 pp.

Forrester J.W., 1968. Principles of Systems $\left(2^{\text {nd }}\right.$ ed.). Waltham, MA, Pegasus Communications, $391 \mathrm{pp}$.

Forrester J.W., 1994. System dynamics, systems thinking, and soft OR. System Dynamics Review, 10(2-3): 245-256.

Gaspar P., Gregoris Y., Lefevre J.M., 1990. A simple eddy kinetic energy model for simulations of the oceanic vertical mixing, tests at station Papa and long-term upper ocean study site. Journal of Geophysical Research, 95(C9): 179-193.

Guo H. C., Liu L., Huang G. H., Fuller G. A., Zou R., Yin Y. Y., 2001. A system dynamics approach for regional environmental planning and management: A study for the Lake Erhai Basin. Journal of Environmental Management, 61: 93-111.

Hajkowicz S., Collins K., 2007. A Review of Multiple Criteria Analysis for Water Resource Planning and Management. Water Resources Management, 21(9): 1553-1566.

Hopkins, T. S., Bailly D., Støttrup J, 2011. A systems approach framework for coastal zones. Ecology and Society 16(4): 25.

Ifremer, 2010. OMEGA_Thau, Phase 1 - Etape 3. Calibration et validation du modèle hydrodynamique MARS-3D couple au module d'entérobactéries sur la lagune de Thau. Partie 2: épisodes pluvieux de novembre 2008 et de février 2009. RST/LER/LR/10-005, 54 pp. + Annexes.

Lazure P., Dumas F., 2008. An external-internal mode coupling for a 3D hydrodynamical model for applications at regional scale (MARS). Advances in Water Resources, 31: 233250.

Mathé S., Rey-Valette H., Pagès S., 2005. Occurrence et évaluation économique d'une fermeture de l'étang de Thau pour cause bactériologique. Deliverable of the DITTY project (Development of an Information Technology Tool for the Management of European Southern Lagoons), EC Contract EVK3-CT-2002-00084, 73 pp. 
Munda G., 2004. Social multi-criteria evaluation: Methodological foundations and operational consequences Original Research Article. European Journal of Operational Research, 158 (3): 662-677.

Munda G., 2005. "Measuring Sustainability": A Multi-Criterion Framework. Environment, Development and Sustainability, 7(1): 117-134.

Pérez Agúndez J. A., Ballé-Beganton J., Mongruel R., Rey-Valette H., Yimam E., 2010. The economic shellfish farming vulnerability due to microbiological contaminations of the Thau lagoon: a modeling approach using an integrative systemic platform. Communication to the ICES Annual Science Conference, September 20-24 2010, Nantes, France.

Raymond M., Delichère S., Boudong C., Fang Z-X., 2010. Innovative development for a modelling approach of the microbiological pollutant sources in the watershed of the Thau lagoon. Proceedings of the $7^{\text {th }}$ international conference on sustainable techniques and strategies in urban water management (Novatech), Lyon, France, June 27-July 12010.

Renn O., 2006. Participatory processes for designing environmental policies. Land Use Policy, 23(1): 34-43.

Rey-Valette H., Damart S., Roussel S., 2007. A multicriteria participation-based methodology for selecting sustainable development indicators: an incentive tool for concerted decision making beyond the diagnosis framework. International Journal of Sustainable Development, 10(1-2): 122-138.

Roussel S., Crinquant N., Bourdat E., 2007. In search of coastal zone sustainability by means of social carrying capacity indicators construction: lessons learned from the Thau Lagoon Case Study (Région Languedoc-Roussillon, France). International Journal of Sustainable Development, 10(1-2): 175-194.

Sobsey M.D., Perdue R., Overton M., Fisher J., 2003. Factors influencing faecal contamination in coastal marinas. Water Science and Technology, 47(3): 199-204.

Sraffa P., 1960. Production of Commodities by Means of Commodities: Prelude to a critique of economic theory. Cambridge, UK, Cambridge University Press.

Stave K. A., 2003. A system dynamic model to facilitate public understanding of water management options in Las Vegas, Nevada. Journal of Environmental Management, 67: 303-313.

Van der Weide J., 1993. A systems view of integrated coastal management. Ocean and Coastal Management, 21(1-3): 129-148.

Varghese K., Ganesh L.S., Monto Mani, Anilkumar P.P., Murthy R., Subramaniam B.R., 2008. Identifying critical variables for coastal profiling in ICZM planning - A systems approach. Ocean and Coastal Management, 51(1): 73-94.

Varma V.K., Ferguson I., Wild I., 2000. Decision support system for the sustainable forest management. Forest Ecology and Management, 128: 49-55.

Von Neumann J., 1945. A Model of General Economic Equilibrium. The Review of Economic Studies, 13(1): 1-9. (First published in German, 1938.) 
Table 1. Water quality standards for the classification of shellfish farming areas and the treatment of shellfish products (EC Regulation No. 854/2004)

\begin{tabular}{|l|l|l|}
\hline $\begin{array}{l}\text { Water quality } \\
\text { classification }\end{array}$ & Microbiological standards & Treatment of shellfish products \\
\hline Class A & $\begin{array}{l}<230 \text { E.coli/100g of flesh } \\
\text { and intravalvular liquid }\end{array}$ & $\begin{array}{l}\text { Shellfish products are acceptable for direct } \\
\text { human consumption. }\end{array}$ \\
\hline Class B & $\begin{array}{l}<600 \text { E.coli/100g of flesh } \\
\text { and intravalvular liquid }\end{array}$ & $\begin{array}{l}\text { Purification in depuration tanks or heat } \\
\text { treatment by an approved process are } \\
\text { required to meet class A standards. }\end{array}$ \\
\hline Class C & $\begin{array}{l}\text { and intravalvular liquid } \\
\text { and }\end{array}$ & $\begin{array}{l}\text { Relaying for a long period or heat } \\
\text { treatment by an approved process are } \\
\text { required to meet class A standards. }\end{array}$ \\
\hline Class D & $>46,000$ E.coli/100g of flesh & $\begin{array}{l}\text { Harvesting and human consumption are } \\
\text { and intravalvular liquid }\end{array}$ \\
\hline
\end{tabular}

Table 2. Principles, criteria, and indicators for the integrated assessment of Thau lagoon water quality policy (SAGE) in the context of the regional management plan (SCOT)

\begin{tabular}{|l|l|l|c|}
\hline \multicolumn{1}{|c|}{ Principles } & \multicolumn{1}{|c|}{ Criteria } & \multicolumn{2}{c|}{ Indicators* } \\
\hline \multirow{2}{*}{$\begin{array}{l}\text { Improving water } \\
\text { quality }\end{array}$} & Bathing water quality & Number of bans (days) & - \\
\cline { 2 - 4 } & Shellfish water quality & Number of bans (days) & - \\
\cline { 2 - 5 } & Lagoon's reputation & Lagoon classification & + \\
\hline \multirow{2}{*}{$\begin{array}{l}\text { Maintaining local } \\
\text { traditional } \\
\text { activities }\end{array}$} & $\begin{array}{l}\text { Employment in traditional } \\
\text { activities }\end{array}$ & $\begin{array}{l}\text { Number of full-time equivalents in } \\
\text { traditional activities }\end{array}$ & + \\
\cline { 2 - 5 } & $\begin{array}{l}\text { Employment in the tourist } \\
\text { industry }\end{array}$ & Number of tourist stays in the region & + \\
\hline development & Total employment & Number of full-time equivalents & + \\
\cline { 2 - 5 } & Economic independence & Trade balance (Exports - Imports) & + \\
\hline
\end{tabular}

* The sign +/- indicates whether the indicator value is expected to increase (+) or decrease (-). 
Table 3. Parameters and processes involved in modeling the production, treatment, and transfer of bacteria in the sub-catchments

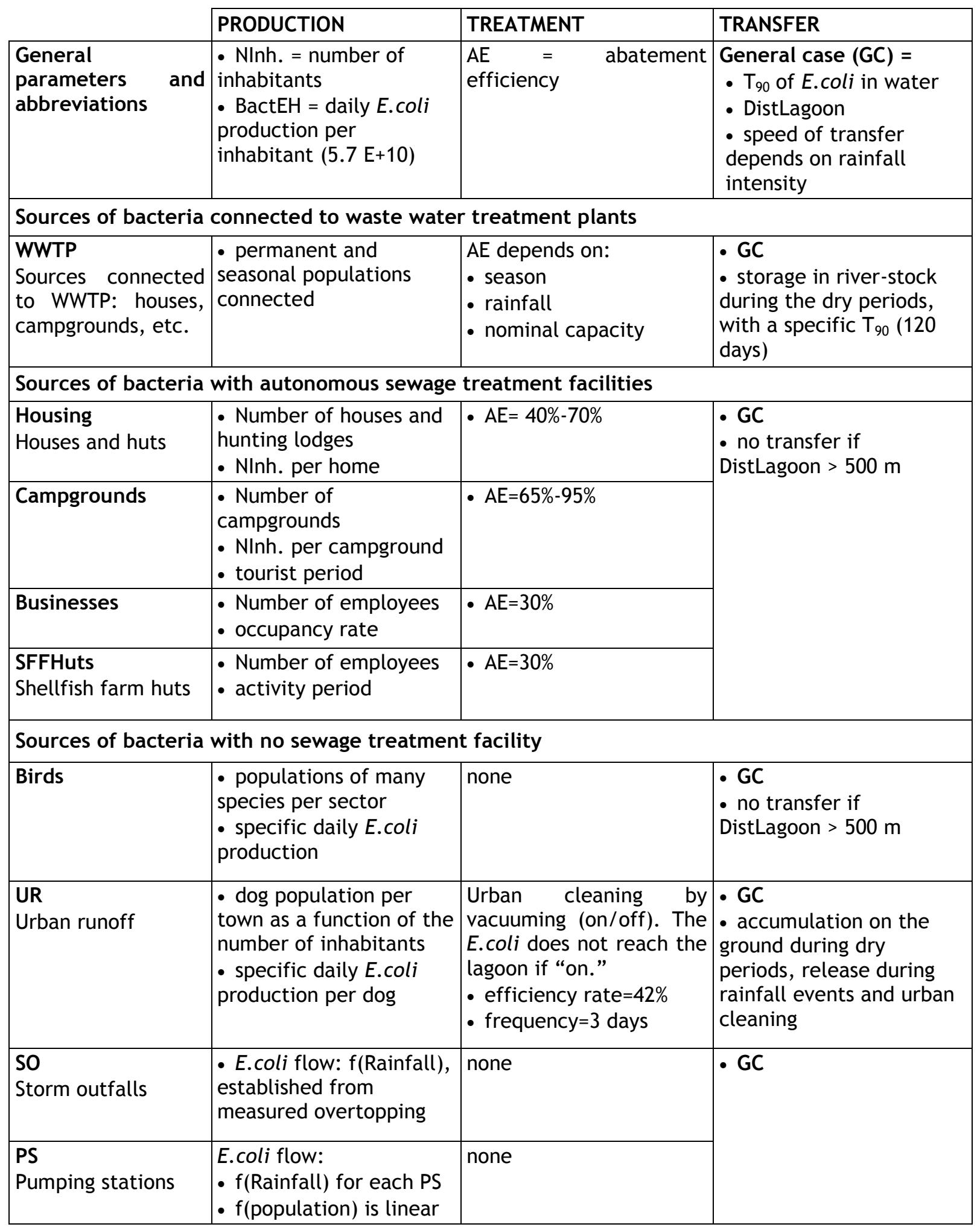


Table 4. Forcing conditions and values of parameters of the MARS-3D lagoon model used to construct the database of contamination simulation results.

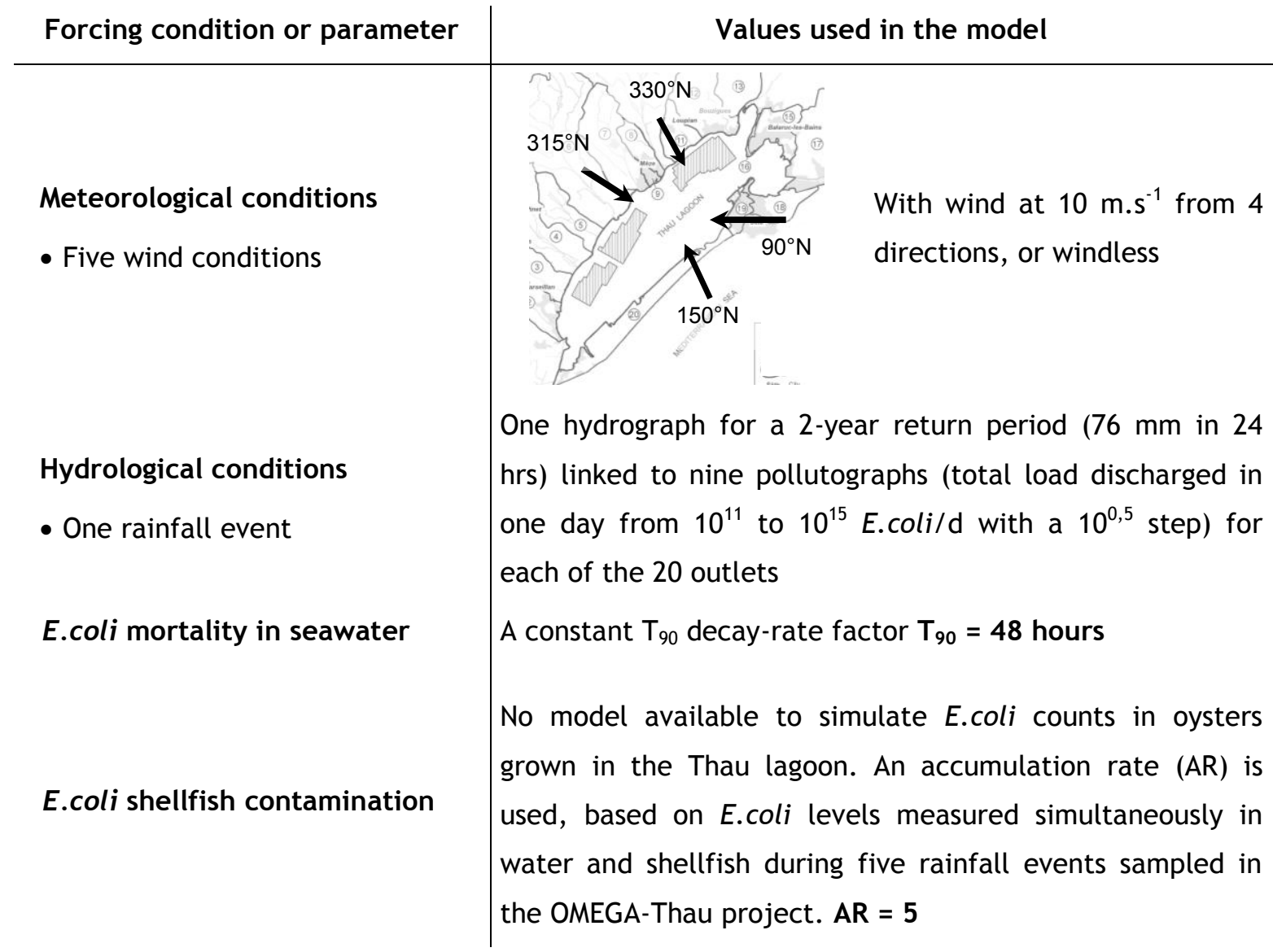

Table 5. Water quality levels and corresponding activity index of dependent sectors.

\begin{tabular}{|c|l|r|r|r|c|}
\hline $\begin{array}{c}\text { Water } \\
\text { quality } \\
\text { levels }\end{array}$ & $\begin{array}{c}\text { Lagoon water quality } \\
\text { classification and } \\
\text { frequency of bans on } \\
\text { beaches and sales }\end{array}$ & $\begin{array}{c}\text { Number of days } \\
\text { of bans during a } \\
5 \text {-year period: } \\
\text { shellfish sales }\end{array}$ & $\begin{array}{c}\text { Number of days } \\
\text { of bans during a } \\
5 \text {-year period: } \\
\text { beach use }\end{array}$ & $\begin{array}{c}\text { Shellfish } \\
\text { farming } \\
\text { activity } \\
\text { index }\end{array}$ & $\begin{array}{c}\text { Tourist } \\
\text { industry } \\
\text { activity } \\
\text { index }\end{array}$ \\
\hline $\mathbf{1}$ & A & 0 & 0 & 95 & 110 \\
\hline 2 & B, very few bans & 0 to $<30$ & 0 to 3 & 105 & 105 \\
\hline 3 & B, low level of bans & 30 to $<60$ & 4 to 7 & 100 & 100 \\
\hline 4 & B, moderate bans & 60 to $<90$ & 8 to 11 & 90 & 90 \\
\hline 5 & B, high level of bans & 90 or more & 12 or more & 50 & 75 \\
\hline 6 & C & n. d. & 12 or more & 0 & 40 \\
\hline
\end{tabular}


Table 6. Comparison of the shellfish contamination levels at REMI monitoring stations and closures of the shellfish area observed and recorded by SPICOSA-Thau, 2003-2009.

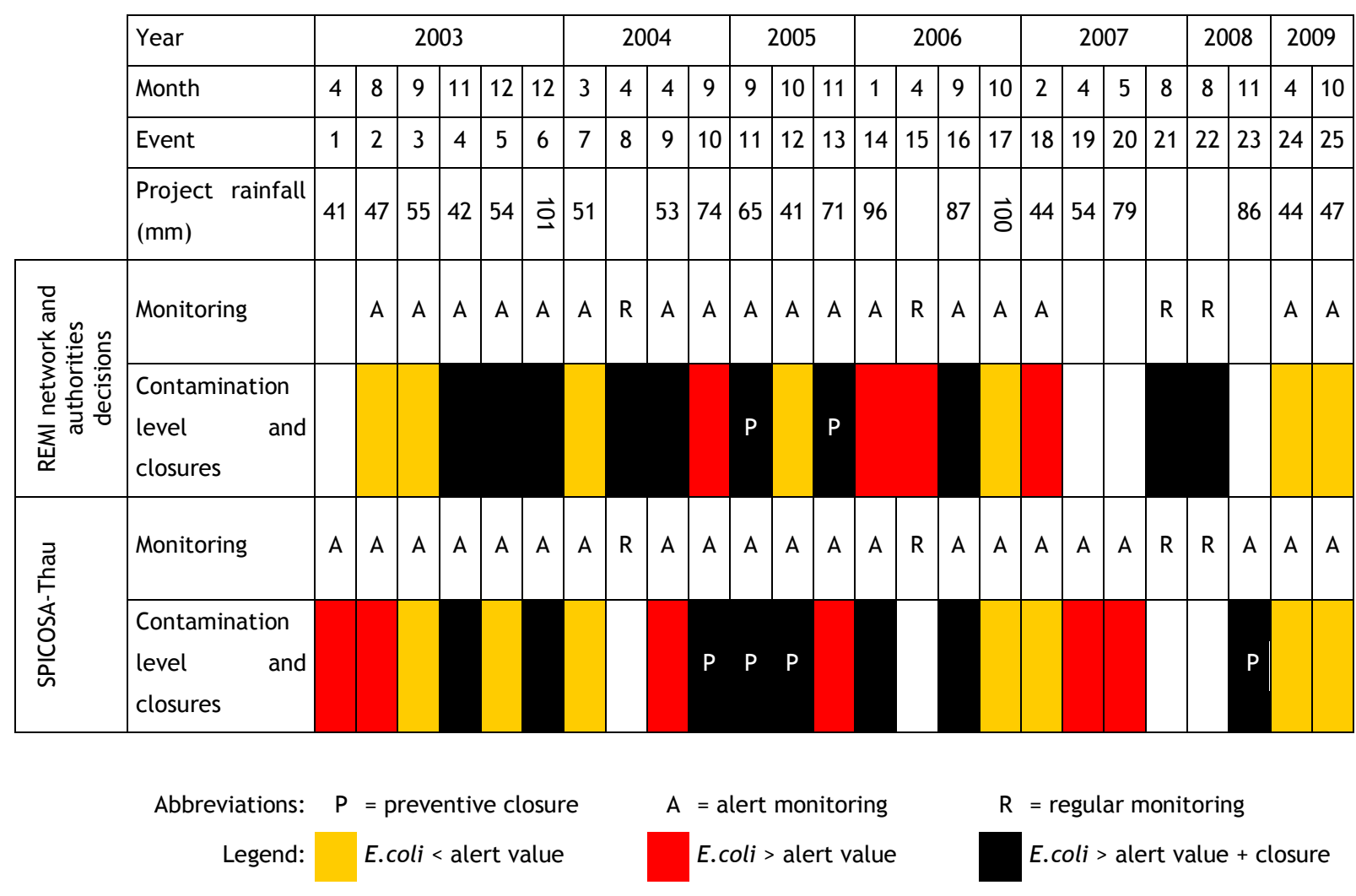

Table 7. Strategic management choices: the simulated technical options.

\begin{tabular}{|l|l|}
\hline Strategic management choice & Combination of technical options \\
\hline Strat_0 & No management measure \\
\hline Strat_1 & Planned_WWTP + Planned_PS \\
\hline Strat_2 & Planned_WWTP + Planned_PS + Option_PS \\
\hline Strat_3 & Planned_WWTP + Planned_PS + Option_PS + Option_UR \\
\hline
\end{tabular}


Table 8. Strategic exploratory scenarios (cumulative results for 2013-2017): impact of strategic management choices on water contamination indicators

\begin{tabular}{|c|c|c|c|c|c|}
\hline $\begin{array}{c}\text { Strategic } \\
\text { management } \\
\text { choice }\end{array}$ & $\begin{array}{c}\text { Number of } \\
\text { bans on } \\
\text { shellfish sales }\end{array}$ & $\begin{array}{c}\text { Duration } \\
\text { (days) of bans } \\
\text { on shellfish } \\
\text { sales }\end{array}$ & $\begin{array}{l}\text { No. of days } \\
\text { above Alert } \\
\text { Threshold } \\
\text { (shellfish) }\end{array}$ & $\begin{array}{c}\text { No. of days } \\
\text { above Alert } \\
\text { Threshold } \\
\text { (beaches) }\end{array}$ & $\begin{array}{c}\text { Water Quality } \\
\text { Level: } \\
\text { shellfish; } \\
\text { beaches }\end{array}$ \\
\hline \multicolumn{6}{|c|}{ 1) Exploratory conditions 1: Wind_adjust; Pop_trend } \\
\hline Strat_0 & 11 & 69 & 26 & 10 & $4 ; 4$ \\
\hline Strat_1 & 10 & 63 & 22 & 6 & $4 ; 3$ \\
\hline Strat_2 & 8 & 51 & 16 & 2 & $3 ; 2$ \\
\hline Strat_3 & 5 & 33 & 11 & 2 & $3 ; 2$ \\
\hline \multicolumn{6}{|c|}{ 2) Exploratory conditions 2: Wind_adjust; Pop_max } \\
\hline Strat_0 & 12 & 75 & 28 & 11 & $4 ; 4$ \\
\hline Strat_1 & 12 & 75 & 28 & 10 & $4 ; 4$ \\
\hline Strat_2 & 9 & 57 & 21 & 5 & $3 ; 3$ \\
\hline Strat_3 & 9 & 57 & 20 & 4 & $3 ; 3$ \\
\hline \multicolumn{6}{|c|}{ 3) Exploratory conditions 3: Wind_max; Pop_trend } \\
\hline Strat_0 & 17 & 111 & 43 & 12 & $5 ; 5$ \\
\hline Strat_1 & 16 & 105 & 39 & 8 & $5 ; 4$ \\
\hline Strat_2 & 13 & 81 & 23 & 4 & $4 ; 3$ \\
\hline Strat_3 & 8 & 48 & 11 & 3 & $3 ; 2$ \\
\hline \multicolumn{6}{|c|}{ 4) Exploratory conditions 4: Wind_max; Pop_max } \\
\hline Strat_0 & 17 & 111 & 44 & 13 & $5 ; 5$ \\
\hline Strat_1 & 17 & 111 & 44 & 12 & $5 ; 5$ \\
\hline Strat_2 & 14 & 87 & 31 & 7 & $4 ; 3$ \\
\hline Strat_3 & 14 & 87 & 30 & 6 & $4 ; 3$ \\
\hline
\end{tabular}


Table 9. Status of the local economy in 2017 , depending on lagoon water quality level

\begin{tabular}{|c|c|c|c|c|}
\hline & Quality 3 & Quality 4 & Quality 5 & Quality 6 \\
\hline \multicolumn{5}{|l|}{ 1- Moderate population growth } \\
\hline Population (inhabitants) & 160,612 & 160,612 & 160,612 & 160,612 \\
\hline Employment in traditional sector & 2,166 & 1,783 & 576 & - \\
\hline Number of tourist stays (in 1000s) & 31,073 & 30,356 & 29,890 & 16,383 \\
\hline Total employment & 52,004 & 51,996 & 51,979 & 52,375 \\
\hline Trade balance in millions of euros & 1,643 & 1,568 & 1,397 & 1,491 \\
\hline \multicolumn{5}{|l|}{ 2- High population growth } \\
\hline Population (inhabitants) & 223,938 & 223,938 & 223,938 & 223,938 \\
\hline Employment in traditional sector & 558 & 618 & 262 & - \\
\hline Number of tourist stays (in 1000s) & 31,623 & 28,641 & 24,070 & 13,085 \\
\hline Total Employment & 73,237 & 73,195 & 73,148 & 73,020 \\
\hline Trade balance in millions of euros & 1,513 & 1,564 & 1,655 & 1,865 \\
\hline
\end{tabular}

\section{Figures}

Figure 1. Watersheds and management perimeters in the "Thau Lagoon" (Lagune de Thau)

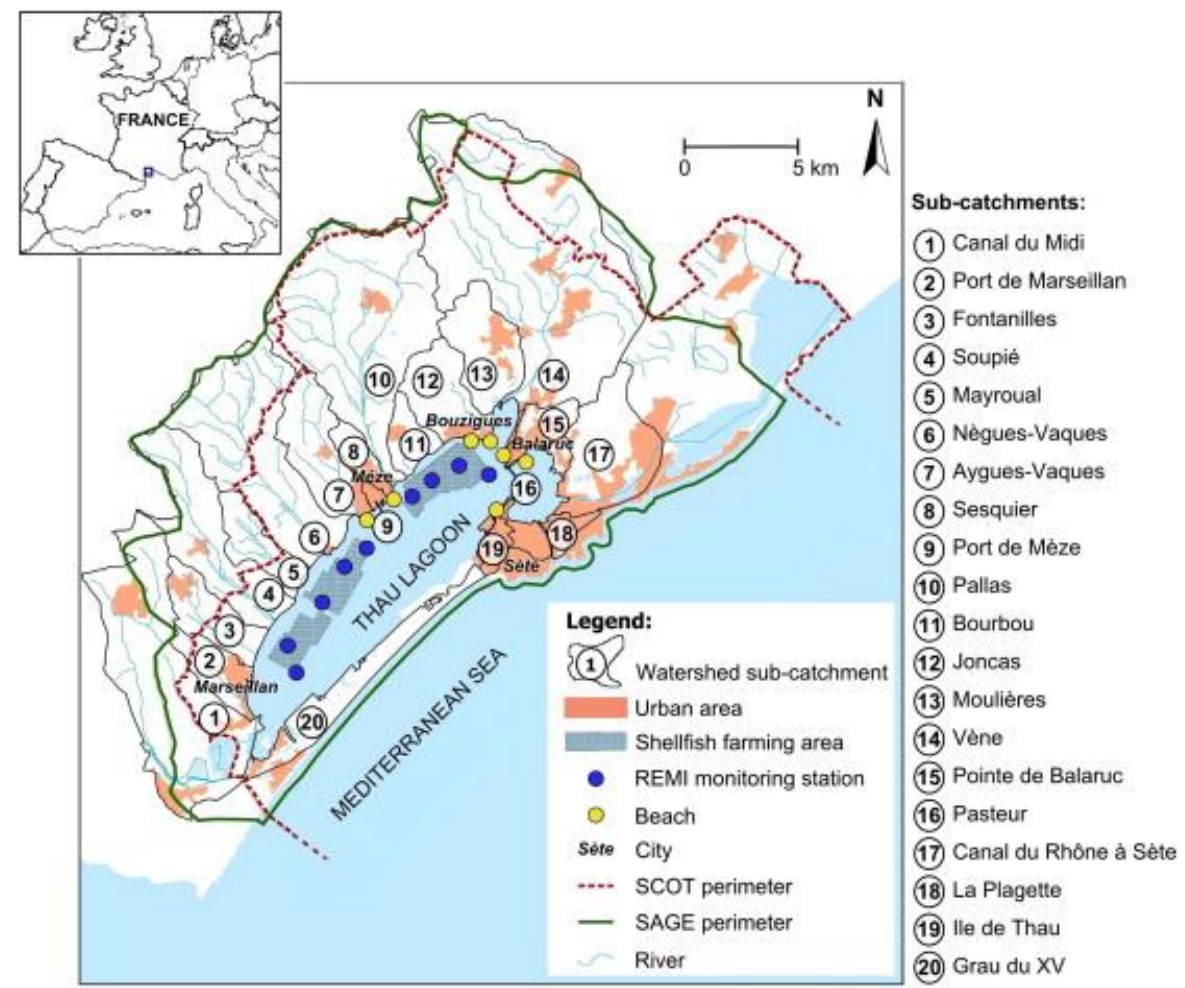


Figure 2. Strategic planning for the mitigation of microbiological contamination in the Thau Lagoon

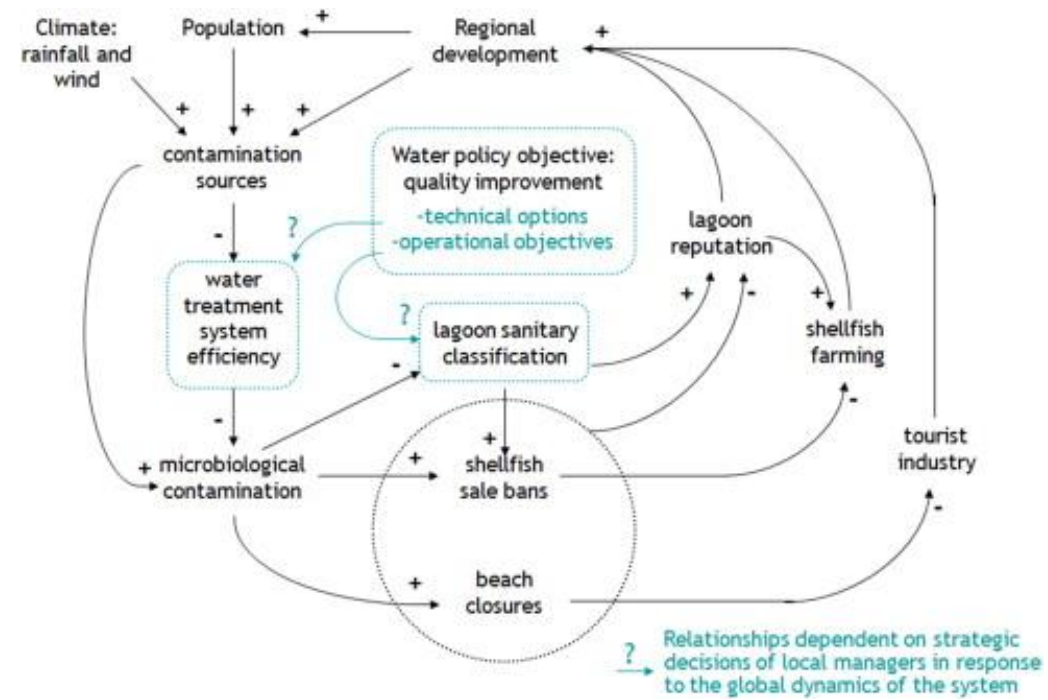

Figure 3. Modeling approach: linking the economic and contamination models

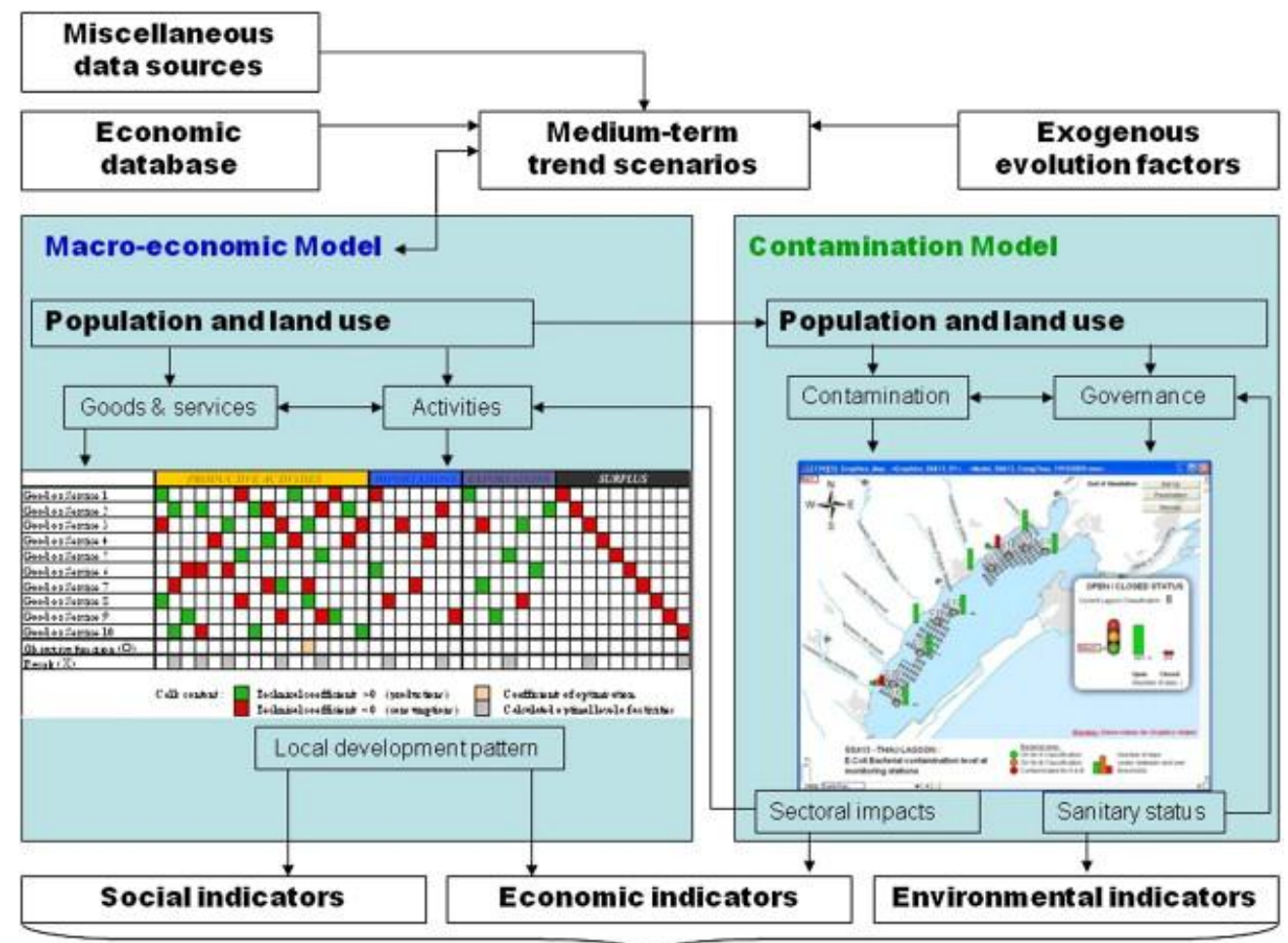

Integrated assessment 
Figure 4. Components of the contamination model developed with ExtendSim

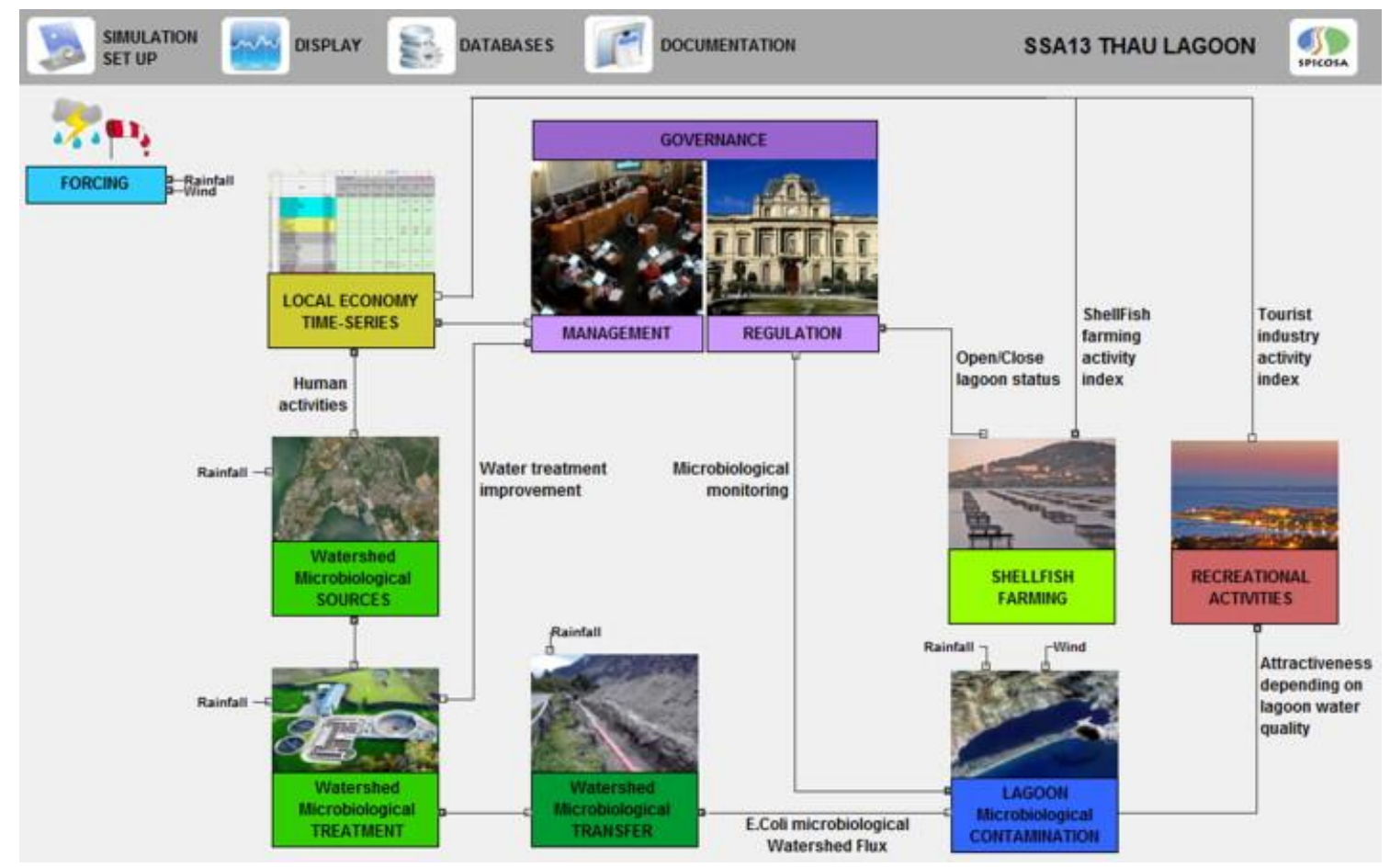

Figure 5. (a) Analytic expressions for the four parameters of the transfer functions expressed in term of E.coli daily flux (F) and distance (D) between outlet and monitoring stations; (b) example of a maximal E.coli level simulated with the MARS-3D model for the Pallas outlet $\left(F=13 \log _{10}\right)$, without wind

(a)

(b) F: Daily E.coll flux

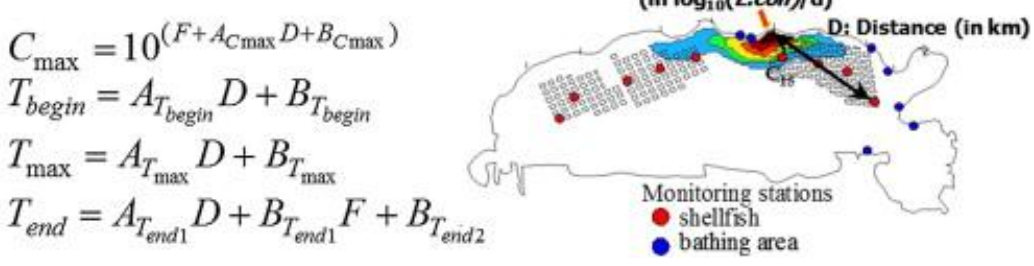


Figure 6. Hypothetical response curves by the shellfish industry and the tourist industry to decreasing levels of water quality

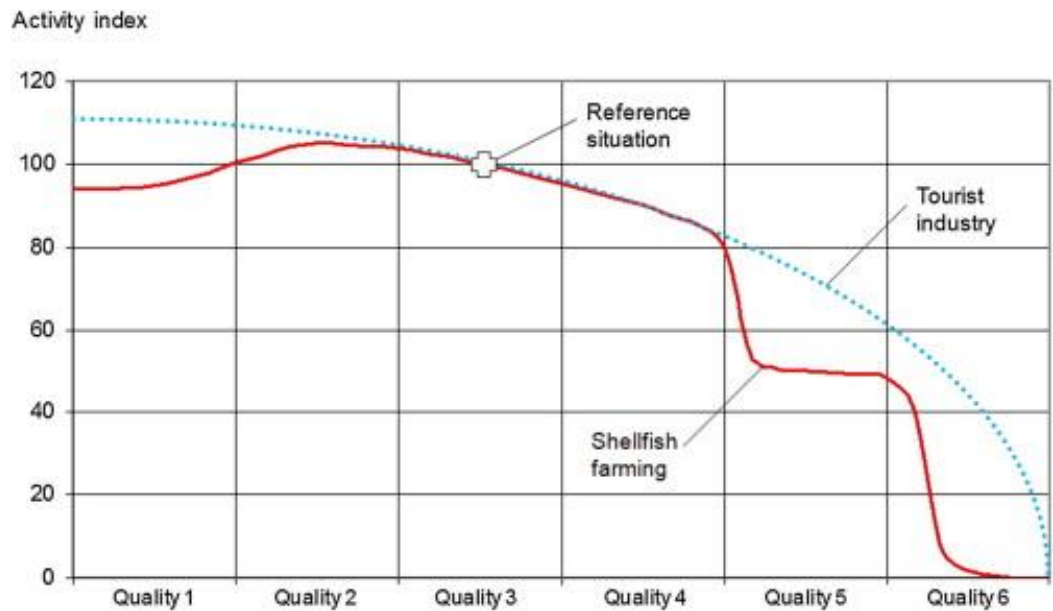

Figure 7. Contribution of the many sources to the E.coli fluxes at the outlets for summer rainfall of $75 \mathrm{~mm} /$ day

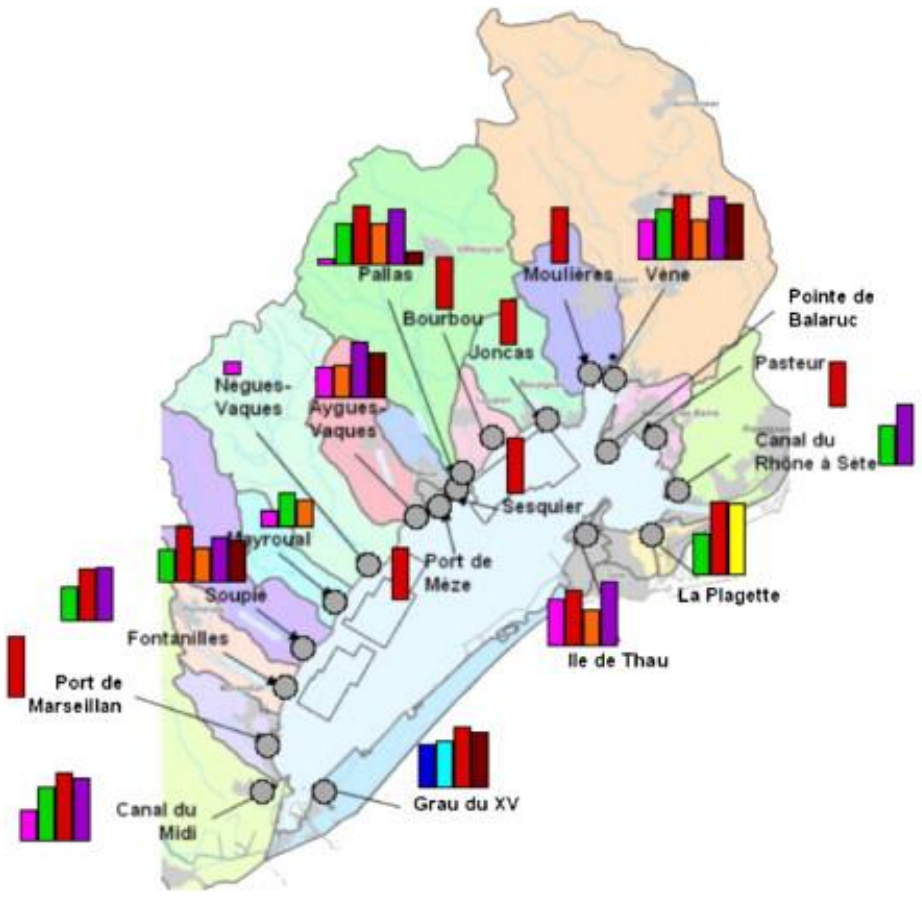

E. coli $(\log 10)$

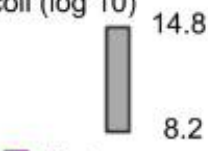

$\square$ Birds

Business

$\square$ Autonomous camping

Autonomous housing

Pumping stations

Shellfish farms huts

$\square$ Storm outfalls

Urban runoff

WWTP 
Figure 8. Comparison of the $E$. coli fluxes by source type as computed by the OMEGA-Thau and SPICOSA-Thau models for summer rainfall of $75 \mathrm{~mm}$

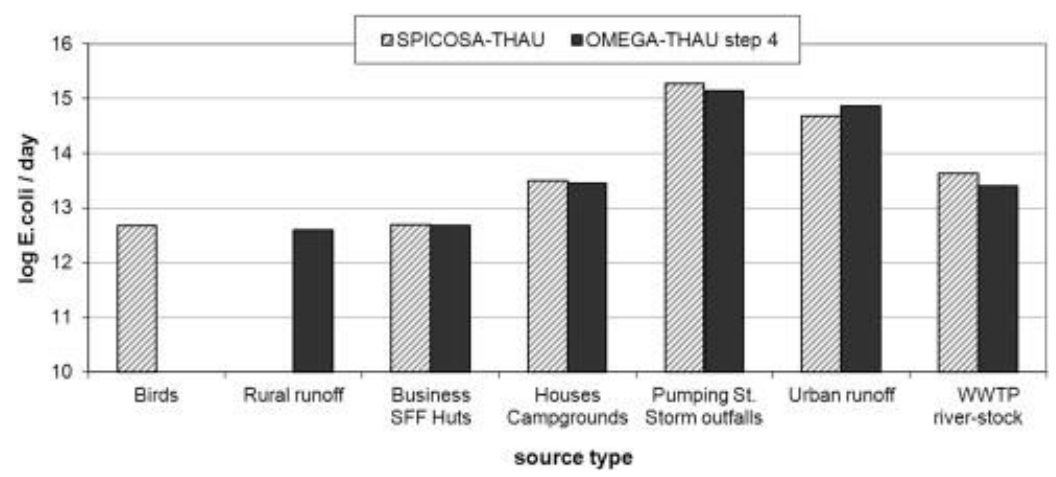

Figure 9. Reference situation (2003-2007) and exploratory scenarios (2013-2017): impact of changes in drivers and governance system on water contamination indicators

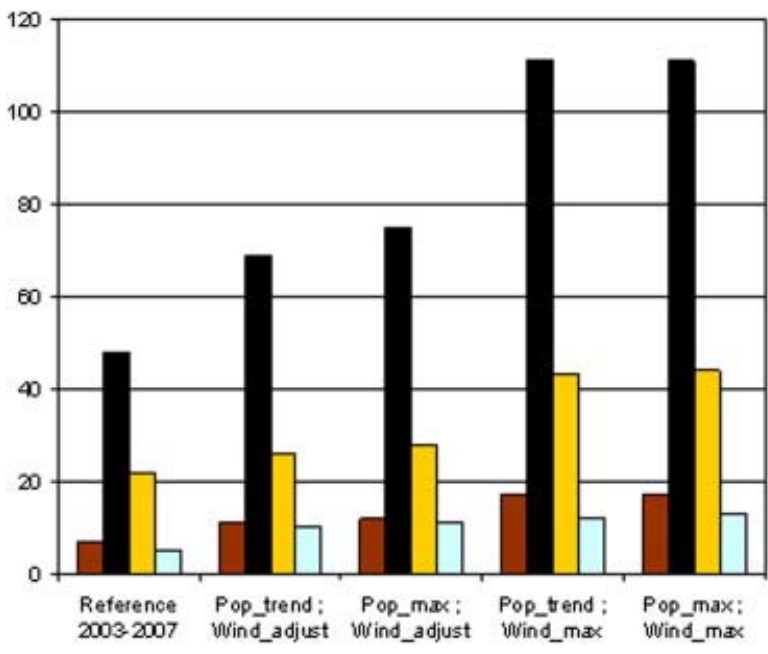

Effects of Population and

Climate change: reference situation and exploratory scenarios with the current monitoring system and the regulation settled in 2010

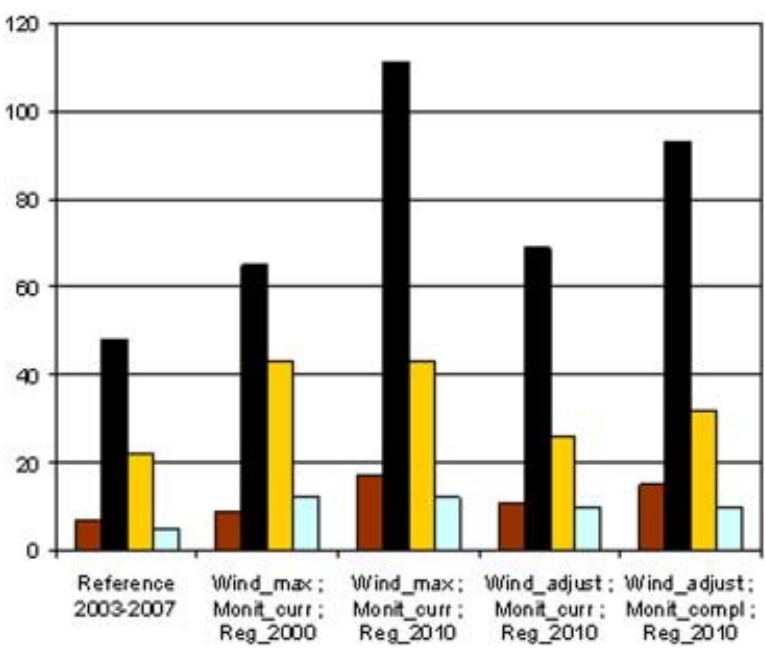

Effects of changes in the regulation and the monitoring system : reference situation and exploratory scenarios with the population grouth of the SCOT (POD trend

anumber of bars for shellfish sales

Duration (days) of bans for shellfish sales

\section{number of days above} Alert Threshold (shelifis h)

anb of days above Alert Threshold (beaches) 